\title{
Fantasy, unrealistic and uncertain aspirations and children's emotional and behavioural adjustment in primary school
}

\author{
Vanessa Moulton \\ Eirini Flouri \\ Heather Joshi \\ Alice Sullivan \\ UCL Institute of Education, University College London \\ vanessa.moulton@gmail.com
}

(Received December 2013 Revised October 2014)

http://dx.doi.org/10.14301/llcs.v6i1.277

\section{Abstract}

We examined the aspirations expressed by 7-year-olds in association with their emotional and behavioural problems, based on data from 12,014 children in the UK's Millennium Cohort Study (MCS). We classified their written responses to the question 'when you grow up, what would you like to be' as aspirations for rare (34.7\%) or non-rare (56.8\%) occupations, fantasy aspirations (1.1\%), aspirations for non-work related future states (2.3\%), and uncertain aspirations (5.1\%). Most children had occupational aspirations, suggesting that at age 7, children already envisage future careers. Though few had fantasy occupations, which are more common in younger children, many gave unrealistic answers which are more developmentally typical for 7-year-olds. Children with fantasy aspirations at age 7 were more hyperactive, and had more conduct and peer problems. Having nonwork-related and uncertain aspirations at this age was not associated with adverse outcomes. Compared to children who aspired to rare occupations, those who aspired to non-rare occupations had more emotional and peer problems. Children with ambitions for rare occupations may have higher self-efficacy and believe they can influence their choices. These findings were robust to adjustment for earlier emotional and behavioural problems, verbal cognitive ability, ethnicity, family structure, social class and poverty, and maternal education and depressed mood.

Keywords: aspirations, emotional and behavioural problems, MCS, seven-year old children

\section{Introduction}

Aspirations reflect what someone would like to achieve rather than what they think they will achieve. Aspirations are hopes and ambitions in an ideal world, while expectations are more realistic assessments for future outcomes, usually taking account of ability and structural constraints. Aspirations in children over 5 tend to reflect the job a child would like to do rather than desires regarding other life domains (Auger, Blackhurst, \& Herting, 2005). Importantly, aspirations are linked to later outcomes.

There has been much research relating aspirations, particularly in adolescence, to later outcomes. High educational and career aspirations during adolescence are associated with greater educational achievement, occupational prestige, and earnings in adulthood (Schoon, Martin, \& Ross, 
2007). By contrast, having low or uncertain educational aspirations in adolescence is related to poorer later outcomes (Gutman, Schoon, \& Sabates, 2012). However, for some adolescents uncertainty about career aspirations also preceded later success (Gutman \& Schoon, 2012). Most of this research is based on the premise that aspirations are related to children's outcomes because they reflect children's achievement goals, optimism and self-esteem (Malmberg, 2002; Nurmi, 1991), and self-efficacy (Bandura, 1995; 1997). Related constructs are locus of control (Rotter, 1966) and expectancy for success (Eccles et al., 1983). Children with an internal locus of control feel they can influence their successes and failures. Similarly, expectancy beliefs are selfbeliefs about success in upcoming tasks, in either the immediate or the long-term future. These constructs drive the development of aspirations and well-being, with high self-efficacy, expectancy beliefs and internal locus of control being associated positively with well-being.

There has been much less research about the role of younger children's aspirations, particularly in emotional and behavioural outcomes. However, early aspirations may be especially important for later outcomes, as they may reflect children's selfefficacy and self-esteem more directly than later aspirations, which are constrained by societal expectations. This Research Note sets out to fill this gap. Using data from the UK Millennium Cohort Study (MCS), we investigated the association between aspirations and emotional and behavioural problems in primary school children.

\section{How aspirations develop}

In general, children's aspirations develop from vague representations of possible future outcomes to more realistic career preferences. Career development theorists argue that children go through a fantasy stage where aspirations are based solely on their interests and desires. Gottfredson (1981) maintains that after age 5, most children no longer report that they aspire to be animals or fantasy characters, or classify adulthood in simple terms (e.g. 'mum', 'tall'). Similarly, more recent work (Atance \& Meltzoff, 2005) suggests that children under the age of 5 have difficulty in representing themselves in future states. By age 7 , children can envisage themselves in the future, but their aspirations "oscillate between fantasy and reality" (Seginer, 2009). In the US, boys tend to report more fantasy aspirations than girls across all ages (Helwig, 2001).

As children grow older, aspirations become more realistic through a process of channelling, selection, adjustment and reflection (Nurmi, 2004). The falling prevalence of expressed fantasy aspirations and the rise of realistic aspirations with age have been supported, for example, by Croll (2008). Children's aspirations are also strongly gendered. Currently, the most popular occupational choices for British adolescents are for girls: hairdresser/beautician, doctor, veterinarian or teacher; and for boys: entertainer/sportsman and the skilled trades (Croll, Attwood \& Fuller, 2010). Ethnicity has also been related to children's aspirations. In Britain, children from ethnic minorities tend to have higher educational and occupational aspirations than white children (Croll et al., 2010). Parents' education, occupation, income and aspirations for their children have all been associated with children's aspirations (Mau \& Bikos, 2000; Schoon et al., 2007). Finally, parental depression is related, both directly and via parenting, to lower optimism and an external locus of control in children.

\section{Aspirations and emotional and behavioural problems}

Aspirations impact on choices and direct future activities, which are themselves related to emotional and behavioural outcomes. The pursuit of one's aspirations has been shown to be beneficial for one's well-being, as it increases the likelihood of goal attainment and a sense of self-efficacy (Bandura, 1997; Eccles et al., 1983). In particular, goals that match the challenges and demands of a particular life stage or situation contribute to an individual's well-being (Nurmi \& Salmela-Aro, 2002). Previous work has focused on the role of aspirations in educational and occupational outcomes rather than other outcomes, such as emotional and behavioural adjustment. Though scarce, empirical evidence on such relationships suggests that they may be important. For example, a study of 12-14 year-olds found that higher academic aspirations for the future were associated with less anti-social behaviour in the present (Boxer, Goldstein, Delorenzo, Savoy, \& Mercado, 2010). Children with higher, compared to lower, future expectations tend to have less anxiety and depression. According to Wyman, Cowen, Work \& 
Kerley (1993), “...future expectations seem to be part of the fabric of a child's ongoing selfexperience and the attitudes and feelings with which he or she engages the world" (p. 658). Using the MCS, Flouri \& Panourgia (2012) showed that high occupational aspirations might contribute to building resilience to externalising problems for primary school children in poverty.

\section{The present investigation}

This Research Note presents an operationalisation of a taxonomy of general types of younger children's aspirations based on the realism of the aspiration and the vocational maturity (Gottfredson, 1981). Other studies have looked at young children's aspirations by social rank (Flouri \& Panouragia, 2012) and a three-way classification of prestige, femininity/masculinity and level of intrinsic/extrinsic motivation (Moulton, Flouri, Joshi \& Sullivan, forthcoming). Using data from the MCS, we investigated the association between aspirations (fantasy, non-work related, uncertain, and for rare and non-rare occupations) and parentreported emotional and behavioural problems in primary school children. We expected that young children who expressed an aspiration for an occupation would have fewer emotional and behavioural problems than children who had nonwork related, fantasy, or uncertain aspirations. Seven year olds who express a fantasy or non-work related aspiration may be falling behind developmentally. Fantasy future orientations may also be an escape from the stresses of everyday life (Nuttin \& Lens, 1985). We therefore expected these children to have more emotional and behavioural problems. Uncertain aspirations may reflect goal avoidance or difficulties in episodic future thinking, which, we hypothesised, would be linked to emotional and behavioural problems. We also expected that children with aspirations for rare occupations would have more positive emotional and behavioural outcomes compared to children aspiring to common (non-rare) occupations. Children aspiring to rare occupations at this age may be expressing unconstrained hopes for the future, evidence that they have high self-efficacy and strong beliefs that they can influence their choices, regardless of the difficulty of their goals.

We adjusted for a number of family- and childlevel variables that may jointly determine aspirations and emotional and behavioural problems in children: family poverty and parental education, social class and mental health (Bradley \& Corwyn, 2002; Nurmi, 1991; Nurmi \& Pulliainen, 1991; Shanahan, Copeland, Costello, \& Angold, 2008).To adjust for children's earlier emotional and behavioural difficulties (Shanahan et al., 2008), we measured children's emotional and behavioural problems both at ages 7 and 5 (at the previous MCS sweep).

\section{Method}

\section{Participants}

We used data from the Millennium Cohort Study (MCS), a birth cohort study of some 19,000 children born in the UK in 2000-02. MCS was designed to over-represent areas with high proportions of ethnic minorities in England, areas of high child poverty, and the three smaller UK countries (Plewis, 2007). We took information from the main respondents (usually the child's mother) and the children themselves at age 7 (Sweep 4), when aspirations were measured for the first time. Sweep 4 included 14,043 children aged around 7, of whom 13,681 were singletons, 332 twins and 30 triplets. We used data from the first four sweeps (at children's ages 9 months, and 3, 5 and 7 years) and from only the first-born twin or triplet, so that we had one cohort member per family. Our analytic sample $(N=12,014)$ comprised those children giving an interpretable response to the aspiration question and a valid score on one of the emotional and behavioural SDQ subscales (see below) at age 7. This sample comprised more girls and children from white backgrounds, with higher verbal ability, and with lower scores on all of the SDQ subscales than the remaining 1,843. Parents in the analytic sample were less likely to be in poverty, and more likely to be in a higher social class. The mothers in the analytic sample were more highly qualified and less likely to be lone parents, and, on average, had lower psychological distress scores.

\section{Measures}

Aspirations were assessed using the children's written responses at age 7 to the open-ended question 'When you grow up, what would you like to be?' If a child needed help understanding or completing the question on their own, the interviewer was available to help them. The children's responses were subsequently coded (Flouri, Moulton, \& Panourgia, 2012). In this 
investigation, children's responses were grouped into five categories. Occupational aspirations were sub-divided into those for 'rare' and 'non-rare' occupations. If the aspired job was held by less than one in a thousand of the UK working population in 2008, when Sweep 4 of MCS took place, then it was labelled 'rare'. 'Non-rare' occupations were those jobs held by more than $0.1 \%$ of the UK working population in 2008. We used the Quarter 2 (AprilJune) 2008 Labour Force Survey (LFS), roughly contemporary with Sweep 4, to identify the proportion of people employed in occupations (coded to the unit groups of the Standard Occupational Classification 2000). Rare occupations, taken together, accounted for a small percentage (6.6\%) of the adult working population in 2008 (LFS), but a high proportion (37.8\%) of the children's occupational aspirations (MCS4). These jobs are typical of children's responses in other studies. 'Rare' occupations included 'sports person', 'vet', 'pop star' or 'spy'. 'Non-rare' occupations included jobs such as 'teacher', 'police officer', 'doctor', 'hairdresser' or 'builder'. The three non-occupational categories were fantasy, descriptive and uncertain aspirations. 'Fantasy' aspirations were 'magical' or not achievable (such as 'royalty', 'superhero', 'fairy'). 'Descriptive' were responses reflecting traits or states of mind (such as 'happy', 'helpful', 'normal', 'good'), or adult roles (such as 'adult', 'tall', ' man', ' mum'). 'Uncertain' aspirations combined the 'don't know' and the few 'nothing' responses.

Emotional and behavioural problems at age 5 and 7 were measured using the main respondent's report of the Strengths and Difficulties Questionnaire (SDQ; Goodman, 1997). The four 'difficulties' subscales were used in this investigation: conduct problems ( $\alpha$ $=0.60)$, hyperactivity $(\alpha=0.78)$, emotional symptoms $(\alpha=0.65)$, and peer problems $(\alpha=0.57)$. Scores on each subscale ranged from 0 to 10 . Few of the children's scores were 'borderline' or 'abnormal' on each of the SDQ subscales (hyperactivity 18.5\%, $\mathrm{M}=3.31, \mathrm{SD}=2.48$; conduct problems $19.5 \%, \mathrm{M}=1.36$, $\mathrm{SD}=1.52$; emotional symptoms $13.2 \%, \mathrm{M}=1.51$, $\mathrm{SD}=1.52$ and peer problems 17.4\%, $\mathrm{M}=1.19$, $\mathrm{SD}=1.52$ ).

The family-level covariates were family poverty, parental social class, lone parenthood, and mother's depressed mood and highest academic qualification. Family poverty was measured (as in Malmberg \& Flouri, 2011) by a four-item summative index of the following socio-economic disadvantages: overcrowding, non-ownership of home, receipt of income support and income poverty). The index ranges from 0 to 4, reflecting a family's level of material deprivation and social exclusion. Family poverty was measured when children were aged 5 and 7 . Mother's depressed mood was assessed by the Kessler Psychological Distress Scale, when the children were aged 5 (Kessler et al, 2003). A 6-item (K6) scale ranging from 0 to $24(\alpha=0.85)$, it measures depressive and anxiety symptoms experienced in the last 30 days. Lone parenthood was a dichotomous variable indicating whether the main respondent had been a single parent at any of the four MCS sweeps. Mother's highest academic qualification as at Sweep 4 ranged from 'no qualification' to 'higher degree'. Parental social class was constructed from information from all four sweeps. The highest value of the National Statistics Socio-economic Classification (NS-SEC) for either parent since Sweep 1 was coded to one of the seven NS-SEC groups, ranging from 'Higher Managerial'/'Professional' to 'Routine'.

The child-level variables were age (in days) at the day of the Sweep 4 interview, gender, ethnicity, and verbal cognitive ability at age 7 . Verbal cognitive ability was measured with the British Ability Scales (BAS) II Reading Achievement scale, which measures word reading ability. Children's scores were adjusted for their age according to the mean scores of the BAS norming group, and were computed using the BAS manual's conversion tables.

\section{Missing data imputation}

Overall, $3.2 \%$ of the values of the explanatory variables in the analytic sample were missing and were identified as not missing completely at random (Little's chi-square $p<0.001$; Little \& Rubin, 2002). A multiple imputation (MI) approach to handling missing data was adopted. Given the level of missingness, five imputed datasets (Graham, Olchowski, \& Gilreath, 2007) were generated in SPSS 20 using the Markov Chain Monte Carlo procedure. The imputation included all the variables in the model, with the exception of the outcome variables (SDQ subscales at Sweep 4), in a fully inclusive model (Collins, Schafer, \& Kam, 2001). We fitted our models in SPSS which pooled the results from the analyses carried out in each imputed dataset. 


\section{Analytic plan}

We first examined the prevalence of different types of response to the aspirations question, and the association of aspirations and emotional and behavioural problems by gender. Then, we fitted a series of multiple linear regression models to each of the emotional and behavioural domain subscales at age 7 . The first model regressed these outcomes on aspirations, gender and ethnicity. We then added the appropriate SDQ subscale at age 5 to adjust for earlier measures of difficulties, thereby focusing on the change in problem behaviour from age 5 to age 7 . Model 3 also included verbal cognitive ability, and the final model added all the remaining covariates. All models controlled for the MCS survey design ('stratum'). We assumed that, conditioning on the design variables, the sampling mechanism is ignorable.

\section{Results}

\section{Descriptives and correlations}

In the analytic sample, over half (56.8\%) of the aspirations were for non-rare occupations, and just over a third (34.7\%) were for rare occupations. Very few children had fantasy $(1.1 \%)$ or descriptive $(2.3 \%)$ aspirations. Some children were uncertain $(5.1 \%)$ of what their aspirations for the future might be.
Table 1 shows the mean SDQ subscale scores in each of the 'aspirations' category by gender. The highest means across all emotional and behavioural problems were for fantasy aspirations, ranging from 4.67 for hyperactivity and 1.62 for peer problems. The lowest problem scores were for aspirations for rare occupations, ranging from 3.26 for hyperactivity and 1.05 for peer problems. Boys averaged significantly higher scores on conduct, peer and hyperactivity problems than girls. Girls had significantly higher scores on emotional symptoms than boys.

\section{Regressions}

Table 2 presents the models for conduct problems. Model 1 showed that, compared to children with aspirations for non-rare occupations, children with fantasy aspirations had more conduct problems at age 7. By contrast, compared to children with aspirations for non-rare occupations, those who aspired to rare occupations had fewer conduct problems. In Model 2, adjusting for conduct problems at age 5 made no difference to terms on aspirations. In Model 3, the association between aspirations for rare occupations and conduct problems became nonsignificant. In Model 4, fantasy aspirations ( $b=$ $0.33,95 \% \mathrm{Cl}: 0.10,0.56)$ remained associated with conduct problems.

Table 1. Mean SDQ subscale scores in each aspiration category by gender

\begin{tabular}{|c|c|c|c|c|c|c|c|c|c|c|c|c|}
\hline \multirow[b]{2}{*}{$\begin{array}{l}\text { Aspiration } \\
\text { category }\end{array}$} & \multicolumn{3}{|c|}{$\begin{array}{l}\text { Conduct problems } \\
\qquad(n=12,007)\end{array}$} & \multicolumn{3}{|c|}{$\begin{array}{l}\text { Hyperactivity } \\
(n=11,965)\end{array}$} & \multicolumn{3}{|c|}{$\begin{array}{l}\text { Emotional symptoms } \\
\qquad(n=11,983)\end{array}$} & \multicolumn{3}{|c|}{$\begin{array}{l}\text { Peer problems } \\
\qquad(n=11,991)\end{array}$} \\
\hline & Total & Boys & Girls & Total & Boys & Girls & Total & Boys & Girls & Total & Boys & Girls \\
\hline $\begin{array}{l}\text { Non-rare } \\
\text { Occupation }\end{array}$ & 1.36 & $1.54^{* * *}$ & $1.22 * * *$ & 3.28 & $3.81 * * *$ & $2.88 * * *$ & 1.56 & 1.53 & 1.58 & 1.27 & $1.41^{* * *}$ & $1.16^{* * *}$ \\
\hline $\begin{array}{l}\text { Rare } \\
\text { Occupation }\end{array}$ & 1.32 & $1.43^{* * *}$ & $1.15 * * *$ & 3.26 & $3.56 * * *$ & $2.81 * * *$ & 1.39 & 1.35 & 1.43 & 1.05 & $1.11^{* *}$ & $.96 * *$ \\
\hline Fantasy & 1.81 & 1.87 & 1.72 & 4.67 & $5.20 * *$ & $3.87 * *$ & 1.94 & 2.09 & 1.71 & 1.62 & 1.61 & 1.63 \\
\hline Descriptive & 1.51 & 1.66 & 1.39 & 3.76 & $4.42 * * *$ & $3.22 * * *$ & 1.62 & 1.57 & 1.66 & 1.36 & $1.60 *$ & $1.16^{*}$ \\
\hline Uncertain & 1.38 & $1.58 * * *$ & $1.12 * * *$ & 3.41 & $3.83 * * *$ & $2.86 * * *$ & 1.63 & 1.69 & 1.56 & 1.19 & $1.34 * *$ & $.99 * *$ \\
\hline Total & 1.36 & $1.51 * * *$ & $1.21 * * *$ & 3.31 & $3.74 * * *$ & $2.88 * * *$ & 1.51 & $1.47^{*}$ & $1.54^{*}$ & 1.19 & $1.29 * * *$ & $1.10 * * *$ \\
\hline
\end{tabular}

Note. Significant mean difference between boys and girls $\left({ }^{*} p<.05,{ }^{* *} p<.01,{ }^{* * *} p<.001\right)$ 
Table 2. Conduct problems at age 7: unstandardised regression coefficients (standard errors) - multiple linear regression $(N=12,007)$

\begin{tabular}{|c|c|c|c|c|}
\hline & 1 & 2 & 3 & 4 \\
\hline $\begin{array}{l}\text { Aspiration: Non-rare occupation (ref) } \\
\text { Rare occupation } \\
\text { Fantasy } \\
\text { Descriptive } \\
\text { Uncertain }\end{array}$ & $\begin{array}{l}-0.08(0.03)^{* *} \\
0.40(0.13)^{* *} \\
0.14(0.09) \\
-0.00(0.06)\end{array}$ & $\begin{array}{c}-0.07(0.03)^{*} \\
0.36(0.12)^{* *} \\
0.12(0.09) \\
-0.01(0.06)\end{array}$ & $\begin{array}{l}-0.04(0.03) \\
0.35(0.12)^{* *} \\
0.07(0.09) \\
-0.02(0.06)\end{array}$ & $\begin{array}{l}-0.02(0.03) \\
0.33(0.12)^{* *} \\
0.03(0.09) \\
0.02(0.06)\end{array}$ \\
\hline $\begin{array}{l}\text { Stratum: England-advantaged (ref) } \\
\text { England-disadvantaged } \\
\text { England-ethnic } \\
\text { Wales-advantaged } \\
\text { Wales-disadvantaged } \\
\text { Scotland-advantaged } \\
\text { Scotland-disadvantaged } \\
\text { Northern Ireland-advantaged } \\
\text { Northern Ireland-disadvantaged }\end{array}$ & $\begin{array}{l}0.39(0.04)^{* * *} \\
0.38(0.07)^{* * *} \\
-0.08(0.07) \\
0.29(0.05)^{* * *} \\
-0.04(0.06) \\
0.23(0.06)^{* * *} \\
-0.24(0.07)^{* *} \\
0.25(0.06)^{* * *}\end{array}$ & $\begin{array}{c}0.25(0.04)^{* * *} \\
0.12(0.09) \\
-0.11(0.06) \\
0.13(0.05)^{*} \\
-0.06(0.06) \\
0.12(0.07) \\
-0.19(0.07) \\
0.09(0.07)\end{array}$ & $\begin{array}{l}0.21(0.04)^{* * *} \\
0.11(0.09) \\
-0.16(0.06)^{*} \\
0.01(0.05) \\
-0.07(0.06) \\
0.06(0.07) \\
-0.26(0.07)^{* * *} \\
-0.03(0.07)\end{array}$ & $\begin{array}{l}0.07(0.04)^{*} \\
-0.08(0.09) \\
-0.14(0.06)^{*} \\
-0.11(0.05)^{*} \\
-0.04(0.06) \\
-0.03(0.07) \\
-0.20(0.07)^{* *} \\
-0.16(0.07)^{*}\end{array}$ \\
\hline Girl & $-.31(0.03)^{* * *}$ & $-0.23(0.03)^{* * *}$ & $-0.21(0.03)^{* * *}$ & $-0.23(0.03)^{* * *}$ \\
\hline $\begin{array}{l}\text { Ethnicity: White (ref) } \\
\text { Mixed } \\
\text { Indian } \\
\text { Pakistani/Bangladeshi } \\
\text { Black/Black British } \\
\text { Other ethnic group }\end{array}$ & $\begin{array}{l}-0.08(0.09) \\
-0.17(0.10) \\
-0.08(0.08) \\
-0.33(0.09)^{* * *} \\
-0.23(0.14)\end{array}$ & $\begin{array}{c}-0.15(0.09) \\
-0.13(0.10) \\
-0.26(0.13) \\
-0.48(0.10)^{* * *} \\
-0.31(0.16) \\
\end{array}$ & $\begin{array}{l}-0.12(0.09) \\
-0.05(0.10) \\
-0.22(0.12) \\
-0.44(0.10)^{* * *} \\
-0.26(0.16)\end{array}$ & $\begin{array}{l}-0.18(0.08)^{*} \\
-0.00(0.10) \\
-0.28(0.11)^{*} \\
-0.53(0.09)^{* * *} \\
-0.27(0.15)\end{array}$ \\
\hline Conduct problems, age 5 & & $0.27(0.03) * * *$ & $0.26(0.02)^{* * *}$ & $0.23(0.02)^{* * *}$ \\
\hline Verbal cognitive ability, age 7 & & & $-0.01(0.00)^{* * *}$ & $-0.01(0.00)^{* * *}$ \\
\hline $\begin{array}{l}\text { Mother's highest qualification: None (ref) } \\
\text { Higher degree } \\
\text { First degree } \\
\text { A level/HE diploma } \\
\text { GCSEa-c } \\
\text { GCSEd-g } \\
\text { Other }\end{array}$ & & & & $\begin{array}{l}-0.20(0.08)^{*} \\
-0.32(0.06)^{* * *} \\
-0.24(0.05)^{* * *} \\
-0.19(0.04)^{* * *} \\
-0.01(0.05) \\
-0.24(0.09)^{*}\end{array}$ \\
\hline $\begin{array}{l}\text { Parents' highest social class: Routine (ref) } \\
\text { Higher managerial/professional } \\
\text { Lower managerial/professional } \\
\text { Intermediate } \\
\text { Small employers } \\
\text { Lower supervisory } \\
\text { Semi-routine }\end{array}$ & & & & $\begin{array}{l}-0.16(0.10) \\
-0.19(0.09) \\
-0.14(0.08) \\
-0.12(0.11) \\
-0.06(0.09) \\
-0.08(0.08) \\
\end{array}$ \\
\hline Family poverty, age 5 & & & & $0.05(0.03)$ \\
\hline Family poverty, age 7 & & & & $0.05(0.02)^{*}$ \\
\hline Ever in lone-parent family & & & & $0.22(0.04)^{* * *}$ \\
\hline Maternal depressed mood, age 5 & & & & $0.04(0.01)^{* *}$ \\
\hline Constant & $1.48(0.41)^{* * *}$ & $1.36(0.42)^{* *}$ & $3.16(0.44)^{* * *}$ & $2.93(0.44)^{* * *}$ \\
\hline R squared adjusted & $0.03-0.03$ & $0.15-0.18$ & $0.17-0.20$ & $0.21-0.23$ \\
\hline
\end{tabular}

Notes. $R$ squared adjusted shows the range of the five imputed datasets for each model. In SPSS 20 a model summary is not given for the pooled results. ${ }^{*} \mathrm{p}<.05,{ }^{* *} \mathrm{p}<.01, * * * \mathrm{p}<.001$ 
The models for hyperactivity are presented in Table 3. Model 1 showed that, compared to children with aspirations for non-rare occupations, children with fantasy or descriptive aspirations were more hyperactive at age 7 , and that children who aspired to rare occupations were less hyperactive. In Model 2 onwards, the terms for descriptive and rare occupational aspirations became nonsignificant. In Models 3 and 4, fantasy aspirations $(b=0.71,95 \% \mathrm{Cl}$ : $0.39,1.04)$ remained associated with hyperactivity.

Table 4 shows the results for emotional symptoms. Model 1 showed that, compared to children with aspirations for non-rare occupations, those with fantasy aspirations had more emotional symptoms and that children with aspirations for rare occupations had fewer. In Models 2 and 3 there was no change in the association with aspirations. In Model 4, the coefficient for fantasy aspirations became nonsignificant, while aspirations for rare occupations $(b=-0.09,95 \% \mathrm{Cl}:-0.15,-0.03)$ remained negatively associated with emotional symptoms.

The models for peer problems are presented in Table 5. Model 1 showed that, compared to children with aspirations for non-rare occupations, children with fantasy aspirations had more peer problems at age 7 , and that those who aspired to rare occupations had fewer peer problems. In Models 2 and 3, adjusting for peer problems at age 5 and verbal cognitive ability made little difference to these estimates. In Model 4, fantasy aspirations remained associated with peer problems $(b=0.26,95 \% \mathrm{Cl}: 0.02$, 0.49 ), and aspirations for rare occupations with fewer peer problems $(b=-0.15,95 \% \mathrm{Cl}:-0.21,-0.10)$.

Looking at the results across outcomes, they have the common feature that neither descriptive nor uncertain aspirations ever show a significant relationship; this is likely to be due to their small numbers. However, the other small category, fantasy aspirations, shows a significant positive difference from non-rare aspirations (more problems) for each type of difficulty, in all models, although there is some attenuation in its size. Nonrare occupations tend to show a negative relationship, but this also attenuates (and, for conduct problems and hyperactivity, loses significance) as the models move towards including other terms. In the full model (4) the estimate for fantasy is better determined for conduct problems, hyperactivity and peer problems, whereas for emotional symptoms, the effect of non-rare occupations is more robust. In terms of the mean of each of the subscales, fantasy aspirations 'raised' the conduct problem score by $24.26 \%$ of its average, hyperactivity by $21.45 \%$ of its average, and peer problems by $21.85 \%$ of the average score. On all outcomes, having a fantasy aspiration raises the problem score more than a non-rare aspiration reduces it. 
Table 3. Hyperactivity at age 7: unstandardised regression coefficients (standard errors) multiple linear regression $(N=11,965)$

\begin{tabular}{|c|c|c|c|c|}
\hline & 1 & 2 & 3 & 4 \\
\hline $\begin{array}{l}\text { Aspiration: Non-rare occupation (ref) } \\
\text { Rare occupation } \\
\text { Fantasy } \\
\text { Descriptive } \\
\text { Uncertain }\end{array}$ & $\begin{array}{l}-0.14(0.05)^{* *} \\
1.22(0.21)^{* * *} \\
0.45(0.15)^{* *} \\
0.07(0.10)\end{array}$ & $\begin{array}{c}-0.05(0.04) \\
0.71(0.17)^{* * *} \\
0.14(0.13) \\
0.08(0.09)\end{array}$ & $\begin{array}{l}-0.00(0.04) \\
0.71(0.17)^{* * *} \\
0.08(0.12) \\
0.06(0.08)\end{array}$ & $\begin{array}{l}0.00(0.04) \\
0.71(0.17)^{* * *} \\
0.07(0.12) \\
0.09(0.08)\end{array}$ \\
\hline $\begin{array}{l}\text { Stratum: England-advantaged (ref) } \\
\text { England-disadvantaged } \\
\text { England-ethnic } \\
\text { Wales-advantaged } \\
\text { Wales-disadvantaged } \\
\text { Scotland-advantaged } \\
\text { Scotland-disadvantaged } \\
\text { Northern Ireland-advantaged } \\
\text { Northern Ireland-disadvantaged }\end{array}$ & $\begin{array}{l}0.51(0.06)^{* * *} \\
0.55(0.11)^{* * *} \\
-0.11(0.11) \\
0.48(0.08)^{* * *} \\
-0.28(0.10)^{* *} \\
0.31(0.10)^{* *} \\
-0.28(0.12)^{*} \\
0.21(0.10)^{*}\end{array}$ & $\begin{array}{c}0.21(0.05)^{* * *} \\
0.31(0.09)^{* *} \\
-0.03(0.09) \\
0.17(0.07)^{*} \\
-0.17(0.08)^{*} \\
0.03(0.08) \\
-0.08(0.10) \\
0.07(0.08)\end{array}$ & $\begin{array}{l}0.14(0.05)^{* *} \\
0.27(0.09)^{* *} \\
-0.11(0.09) \\
-0.01(0.07) \\
-0.19(0.08)^{*} \\
-0.05(0.08) \\
-0.18(0.10) \\
-0.13(0.08)\end{array}$ & $\begin{array}{l}0.08(0.05) \\
0.18(0.09) \\
-0.10(0.09) \\
-0.07(0.07) \\
-0.18(0.08)^{*} \\
-0.10(0.08) \\
-0.06(0.08) \\
-0.18(0.08)^{*}\end{array}$ \\
\hline Girl & $-.89(0.05)^{* * *}$ & $-0.42(0.04)^{* * *}$ & $-0.39(0.04) * * *$ & $-0.41(0.04)^{* * *}$ \\
\hline $\begin{array}{l}\text { Ethnicity: White (ref) } \\
\text { Mixed } \\
\text { Indian } \\
\text { Pakistani/Bangladeshi } \\
\text { Black/Black British } \\
\text { Other ethnic group }\end{array}$ & $\begin{array}{l}-0.06(0.14) \\
-0.12(0.16) \\
0.13(0.13) \\
-0.57(0.14)^{* * *} \\
-0.18(0.22)\end{array}$ & $\begin{array}{c}-0.17(0.12) \\
-0.20(0.13) \\
-0.12(0.11) \\
-0.46(0.12)^{* * *} \\
-0.28(0.31)\end{array}$ & $\begin{array}{l}-0.12(0.11) \\
-0.08(0.12) \\
-0.07(0.10) \\
-0.42(0.11)^{* * *} \\
-0.21(0.30)\end{array}$ & $\begin{array}{l}-0.17(0.12) \\
-0.06(0.12) \\
-0.10(0.11) \\
-0.50(0.12)^{* * *} \\
-0.25(0.30)\end{array}$ \\
\hline Hyperactivity, age 5 & & $0.65(0.01)^{* * *}$ & $0.62(0.01)^{* * *}$ & $0.60(0.01)^{* * *}$ \\
\hline Verbal cognitive ability, age 7 & & & $-0.02(0.00)^{* * *}$ & $-0.02(0.00) * * *$ \\
\hline $\begin{array}{l}\text { Mother's highest qualification: None } \\
\text { (ref) } \\
\text { Higher degree } \\
\text { First degree } \\
\text { A level/HE diploma } \\
\text { GCSEa-c } \\
\text { GCSEd-g } \\
\text { Other }\end{array}$ & & & & $\begin{array}{l}0.08(0.11) \\
-0.04(0.08) \\
0.02(0.07) \\
0.07(0.07) \\
0.01(0.08) \\
0.29(0.14)^{*}\end{array}$ \\
\hline $\begin{array}{l}\text { Parents' highest social class: Routine } \\
\text { (ref) } \\
\text { Higher managerial/professional } \\
\text { Lower managerial/professional } \\
\text { Intermediate } \\
\text { Small employers } \\
\text { Lower supervisory } \\
\text { Semi-routine }\end{array}$ & & & & $\begin{array}{l}0.06(0.10) \\
0.09(0.10) \\
0.05(0.10) \\
0.01(0.11) \\
0.07(0.10) \\
0.18(0.10)\end{array}$ \\
\hline Family poverty, age 5 & & & & $0.04(0.03)$ \\
\hline Family poverty, age 7 & & & & $0.05(0.03)$ \\
\hline Ever in lone-parent family & & & & $0.09(0.05)$ \\
\hline Maternal depressed mood, age 5 & & & & $0.02(0.00)^{* *}$ \\
\hline Constant & $6.59(0.66)^{* * *}$ & $3.41(0.53)^{* * *}$ & $6.27(0.55)^{* * *}$ & $6.00(0.56)^{* * *}$ \\
\hline R squared adjusted & $0.05-0.05$ & $0.40-0.41$ & $0.42-0.43$ & $0.42-0.43$ \\
\hline
\end{tabular}

Notes. $R$ squared adjusted shows the range of the five imputed datasets for each model. In SPSS 20 a model summary is not given for the pooled results. ${ }^{*} \mathrm{p}<.05,{ }^{* *} \mathrm{p}<.01,{ }^{* * *} \mathrm{p}<.001$ 
Table 4. Emotional symptoms at age 7: unstandardised regression coefficients (standard errors) multiple linear regression $(\mathrm{N}=11,983)$

\begin{tabular}{|c|c|c|c|c|}
\hline & 1 & 2 & 3 & 4 \\
\hline $\begin{array}{l}\text { Aspiration: Non-rare occupation (ref) } \\
\text { Rare occupation } \\
\text { Fantasy } \\
\text { Descriptive } \\
\text { Uncertain }\end{array}$ & $\begin{array}{l}-0.14(0.04)^{* * *} \\
0.40(0.15)^{* *} \\
0.06(0.11) \\
0.12(0.07)\end{array}$ & $\begin{array}{l}-0.11(0.03)^{* *} \\
0.29(0.14)^{*} \\
-0.02(0.10) \\
0.04(0.07)\end{array}$ & $\begin{array}{l}-0.11(0.03)^{* *} \\
0.29(0.14)^{*} \\
-0.02(0.10) \\
-0.04(0.07)\end{array}$ & $\begin{array}{l}-0.09(0.03)^{* *} \\
0.27(0.14) \\
-0.52(0.10) \\
0.08(0.07)\end{array}$ \\
\hline $\begin{array}{l}\text { Age } \\
\text { Stratum: England-advantaged (ref) } \\
\text { England-disadvantaged } \\
\text { England-ethnic } \\
\text { Wales-advantaged } \\
\text { Wales-disadvantaged } \\
\text { Scotland-advantaged } \\
\text { Scotland-disadvantaged } \\
\text { Northern Ireland-advantaged } \\
\text { Northern Ireland-disadvantaged }\end{array}$ & $\begin{array}{l}0.29(0.04)^{* * *} \\
0.34(0.08)^{* * *} \\
-0.08(0.08) \\
0.12(0.06) \\
-0.18(0.07)^{* *} \\
0.07(0.07) \\
-0.06(0.08) \\
0.17(0.07)^{*}\end{array}$ & $\begin{array}{c}0.19(0.04)^{* * *} \\
0.17(0.07)^{*} \\
-0.12(0.07) \\
0.02(0.10) \\
-0.18(0.07)^{*} \\
-0.07(0.11) \\
-0.06(0.08) \\
0.04(0.10)\end{array}$ & $\begin{array}{l}0.14(0.04)^{* *} \\
0.15(0.07)^{*} \\
-0.16(0.08)^{*} \\
-0.09(0.10) \\
-0.19(0.07)^{* *} \\
-0.12(0.11) \\
-0.11(0.08) \\
-0.07(0.10)\end{array}$ & $\begin{array}{l}0.05(0.04) \\
0.01(0.07) \\
-0.15(0.07)^{*} \\
-0.18(0.09) \\
-0.17(0.07)^{*} \\
-0.19(0.10) \\
-0.06(0.08) \\
-0.15(0.10)\end{array}$ \\
\hline Girl & $.05(0.03)$ & $0.02(0.03)$ & $0.05(0.03)$ & $0.05(0.03)$ \\
\hline $\begin{array}{l}\text { Ethnicity: White (ref) } \\
\text { Mixed } \\
\text { Indian } \\
\text { Pakistani/Bangladeshi } \\
\text { Black/Black British } \\
\text { Other ethnic group }\end{array}$ & $\begin{array}{l}-0.12(0.10) \\
-0.06(0.11) \\
0.29(0.09)^{* *} \\
-0.25(0.10)^{*} \\
0.14(0.15)\end{array}$ & $\begin{array}{c}-0.25(0.13) \\
-0.13(0.11) \\
0.05(0.11) \\
-0.63(0.18)^{*} \\
-0.06(0.19)\end{array}$ & $\begin{array}{l}-0.23(0.13) \\
-0.07(0.11) \\
0.08(0.11) \\
-0.59(0.18)^{*} \\
-0.02(0.19)\end{array}$ & $\begin{array}{l}-0.29(0.12)^{*} \\
-0.02(0.11) \\
0.04(0.10) \\
-0.66(0.16)^{* *} \\
-0.08(0.19)\end{array}$ \\
\hline Emotional symptoms, age 5 & & $0.33(0.05)^{* *}$ & $0.33(0.05)^{* *}$ & $0.30(0.05)^{* *}$ \\
\hline Verbal cognitive ability, age 7 & & & $-0.01(0.00)^{* * *}$ & $-0.01(0.00)^{* * *}$ \\
\hline $\begin{array}{l}\text { Mother's highest qualification: None } \\
\text { (ref) } \\
\text { Higher degree } \\
\text { First degree } \\
\text { A level/HE diploma } \\
\text { GCSEa-C } \\
\text { GCSEd-g } \\
\text { Other }\end{array}$ & & & & $\begin{array}{l}-0.07(0.10) \\
-0.12(0.08) \\
-0.09(0.07) \\
-0.07(0.06) \\
-0.01(0.10) \\
-0.14(0.16)\end{array}$ \\
\hline $\begin{array}{l}\text { Parents' highest social class: Routine } \\
\text { (ref) } \\
\text { Higher managerial/professional } \\
\text { Lower managerial/professional } \\
\text { Intermediate } \\
\text { Small employers } \\
\text { Lower supervisory } \\
\text { Semi-routine }\end{array}$ & & & & $\begin{array}{l}0.03(0.10) \\
0.07(0.09) \\
-0.02(0.09) \\
0.08(0.09) \\
0.08(0.09) \\
0.15(0.09)\end{array}$ \\
\hline Family poverty, age 5 & & & & $0.05(0.03)$ \\
\hline Family poverty, age 7 & & & & $0.02(0.03)$ \\
\hline Ever in lone-parent family & & & & $0.19(0.05)^{* * *}$ \\
\hline Maternal depressed mood, age 5 & & & & $0.06(0.01)^{* * *}$ \\
\hline Constant & $1.07(0.47)^{*}$ & $.99(0.45)^{*}$ & $2.52(0.48)^{* * *}$ & $2.10(0.49)^{* * *}$ \\
\hline$\overline{\text { R squared adjusted }}$ & $0.01-0.01$ & $0.14-0.19$ & $0.15-0.20$ & $0.17-0.21$ \\
\hline
\end{tabular}

Notes. $R$ squared adjusted shows the range of the five imputed datasets for each model. In SPSS 20 a model summary is not given for the pooled results. ${ }^{*} \mathrm{p}<.05, * * \mathrm{p}<.01, * * * \mathrm{p}<.001$ 
Table 5. Peer problems at age 7: unstandardized regression coefficients (standard errors) multiple linear regression $(N=11,991)$

\begin{tabular}{|c|c|c|c|c|}
\hline & 1 & 2 & 3 & 4 \\
\hline $\begin{array}{l}\text { Aspiration: Non-rare occupation (ref) } \\
\text { Rare occupation } \\
\text { Fantasy } \\
\text { Descriptive } \\
\text { Uncertain }\end{array}$ & $\begin{array}{l}-0.21(0.03)^{* * *} \\
0.33(0.13)^{*} \\
0.07(0.09) \\
-0.05(0.06)\end{array}$ & $\begin{array}{c}-0.19(0.03)^{* * *} \\
0.28(0.12)^{*} \\
-0.01(0.09) \\
-0.07(0.06)\end{array}$ & $\begin{array}{l}-0.17(0.03)^{* * *} \\
0.27(0.12)^{*} \\
-0.04(0.09) \\
-0.08(0.06)\end{array}$ & $\begin{array}{l}-0.15(0.03)^{* * *} \\
0.26(0.12)^{*} \\
-0.06(0.09) \\
-0.04(0.06)\end{array}$ \\
\hline$\underline{\text { Age }}$ & $-0.04(0.06)$ & $-0.08(0.06)$ & $-0.12(0.06)^{*}$ & $-0.14(0.06)^{*}$ \\
\hline $\begin{array}{l}\text { Stratum: England-advantaged (ref) } \\
\text { England-disadvantaged } \\
\text { England-ethnic } \\
\text { Wales-advantaged } \\
\text { Wales-disadvantaged } \\
\text { Scotland-advantaged } \\
\text { Scotland-disadvantaged } \\
\text { Northern Ireland-advantaged } \\
\text { Northern Ireland-disadvantaged }\end{array}$ & $\begin{array}{l}0.36(0.04)^{* * *} \\
0.32(0.07)^{* * *} \\
-0.10(0.07) \\
0.19(0.05)^{* * *} \\
-0.16(0.06)^{* *} \\
0.15(0.06)^{*} \\
-0.24(0.07)^{* *} \\
0.13(0.06)^{*}\end{array}$ & $\begin{array}{c}0.25(0.04)^{* * *} \\
0.12(0.09) \\
-0.14(0.07) \\
0.08(0.05) \\
-0.18(0.06)^{* *} \\
0.04(0.07) \\
-0.25(0.07)^{* * *} \\
0.02(0.07)\end{array}$ & $\begin{array}{l}0.21(0.04)^{* * *} \\
0.10(0.09) \\
-0.17(0.07)^{*} \\
-0.01(0.05) \\
-0.19(0.06)^{* *} \\
-0.00(0.06) \\
-0.30(0.07)^{* * *} \\
-0.07(0.07)\end{array}$ & $\begin{array}{l}0.11(0.04)^{* *} \\
-0.04(0.09) \\
-0.15(0.07)^{*} \\
-0.10(0.05) \\
-0.16(0.06)^{* *} \\
--0.08(0.06) \\
-0.24(0.07)^{* *} \\
-0.16(0.07)^{*}\end{array}$ \\
\hline Girl & $-.22(0.03)^{* * *}$ & $-0.18(0.03)^{* * *}$ & $-0.16(0.03)^{* * *}$ & $-0.17(0.03)^{* * *}$ \\
\hline $\begin{array}{l}\text { Ethnicity: White (ref) } \\
\text { Mixed } \\
\text { Indian } \\
\text { Pakistani/Bangladeshi } \\
\text { Black/Black British } \\
\text { Other ethnic group }\end{array}$ & $\begin{array}{l}0.18(0.09)^{*} \\
0.32(0.10)^{* *} \\
0.63(0.08)^{* * *} \\
0.14(0.09) \\
0.27(0.14)^{*}\end{array}$ & $\begin{array}{c}0.12(0.09) \\
0.21(0.11) \\
0.31(0.12)^{*} \\
-0.07(0.09) \\
0.08(0.16)\end{array}$ & $\begin{array}{l}0.14(0.09) \\
0.27(0.11)^{*} \\
0.34(0.12)^{*} \\
-0.04(0.09) \\
0.12(0.16)\end{array}$ & $\begin{array}{l}0.07(0.09) \\
0.32(0.11)^{* *} \\
0.30(0.11)^{*} \\
-0.11(0.09) \\
0.06(0.16)\end{array}$ \\
\hline Peer problems, age 5 & & $0.22(0.01)^{* * *}$ & $0.21(0.01)^{* * *}$ & $0.20(0.01)^{* * *}$ \\
\hline Verbal cognitive ability, age 7 & & & $-0.01(0.00)^{* * *}$ & $-0.01(0.00)^{* * *}$ \\
\hline $\begin{array}{l}\text { Mother's highest qualification: None } \\
\text { (ref) } \\
\text { Higher degree } \\
\text { First degree } \\
\text { A level/HE diploma } \\
\text { GCSEa-C } \\
\text { GCSEd-g } \\
\text { Other }\end{array}$ & & & & $\begin{array}{l}-0.07(0.08) \\
-0.10(0.07) \\
-0.07(0.05) \\
-0.02(0.05) \\
0.01(0.07) \\
0.13(0.11)\end{array}$ \\
\hline $\begin{array}{l}\text { Parents' highest social class: Routine } \\
\text { (ref) } \\
\text { Higher managerial/professional } \\
\text { Lower managerial/professional } \\
\text { Intermediate } \\
\text { Small employers } \\
\text { Lower supervisory } \\
\text { Semi-routine }\end{array}$ & & & & $\begin{array}{l}0.00(0.09) \\
0.07(0.08) \\
-0.02(0.09) \\
0.11(0.09) \\
0.13(0.10) \\
0.13(0.08)\end{array}$ \\
\hline Family poverty, age 5 & & & & $0.07(0.03)^{*}$ \\
\hline Family poverty, age 7 & & & & $0.01(0.03)$ \\
\hline Ever in lone-parent family & & & & $0.22(0.04)^{* * *}$ \\
\hline Maternal depressed mood, age 5 & & & & $0.05(0.01)^{* * *}$ \\
\hline Constant & $1.48(0.41)^{* * *}$ & $1.54(0.41)^{* * *}$ & $2.85(0.43)^{* * *}$ & $2.39(0.42)^{* * *}$ \\
\hline R squared adjusted & $0.05-0.05$ & $0.40-0.42$ & $0.42-0.43$ & $0.42-0.43$ \\
\hline
\end{tabular}

Notes. $R$ squared adjusted shows the range of the five imputed datasets for each model. In SPSS 20 a model summary is not given for the pooled results. ${ }^{*} \mathrm{p}<.05,{ }^{* *} \mathrm{p}<.01,{ }^{* * *} \mathrm{p}<.001$ 


\section{Discussion}

This Research Note presents an operational-isation of a taxonomy of the aspirations of primary school age children, based on data which had never previously been collected on such a large scale for this age. It explores the association of the type and maturity of the aspiration with the children's emotional and behavioural problems. Using data from the Millennium Cohort Study (MCS), we found, as expected, an association between seven-year-old children's aspirations and their emotional and behavioural problems at age 7. For most (91.5\%) children in our sample, their first reported aspirations were occupational, suggesting that at age 7 children may already have dreams or ambitions for future careers. Children giving fantasy aspirations were more likely than children with aspirations for non-rare occupations to be hyperactive and have conduct and peer problems at age 7. Compared to aspirations for non-rare occupations, aspirations for rare occupations were associated with fewer peer problems and emotional symptoms.

This exploratory study showed that very few (1.1\%) of the seven-year-olds in MCS aspired to be fantasy characters but many children (34.7\%) had hopes for rare occupations. Rare occupational aspirations at this age may be an expression of hopes for the future, free from constraints. Children with ambitions for rare occupations may have higher self-efficacy and selfesteem and believe they can influence their choices regardless of the difficulty of their goals. This confidence in their abilities may also be reflected, in part, in their positive relations with peers. By contrast, fantasy aspirations at age 7 were associated with hyperactivity, conduct and peer problems. Although these findings may just represent how articulate the children are, which is linked to behavioural adjustment, this pattern of results accords with previous findings (Gottfredson, 1981) that children showing magical thinking in middle childhood may be behind on their development.

Some of our findings were unexpected. We had hypothesised that descriptive and uncertain aspirations would be associated with negative child outcomes. Uncertain aspirations were not associated with negative child outcomes, also found in Gutman and Schoon's (2012) study of uncertain adolescent aspirations. It seems that having uncertain occupational aspirations at age 7 and in adolescence does not result in negative outcomes, unlike having uncertain educational aspirations. Finally, age 7 descriptive aspirations were related to hyperactivity, but the association was not robust to adjustment for age 5 hyperactivity. A reason for this may be the heterogeneity of the responses labelled as descriptive aspirations. These ranged from desired physical attributes (e.g., 'tall') and emotional states (e.g., 'happy') to hopes for adult roles ('mum'). Some of these responses need not imply developmental difficulties. In the future, a more refined coding scheme could address this heterogeneity.

This Research Note has its limitations. The use of a large cohort is an important strength, but, as with all multi-purpose studies, there were limits to the scope of the questions included. Although the MCS children were given the opportunity to describe their aspirations in as much detail as they wished, they were not asked about the reasons for their choices. In addition, the aspiration question has so far been asked only in one sweep, and so no validation across sweeps can be made. Further, it is not clear how 'aligned' or 'misaligned' the children's aspirations were with their expectations. The seven-year-olds in MCS were not asked what they expected to be or thought they would be. Without asking directly about expectations, we cannot know whether some of them really thought they would be 'footballers' or 'fairies', for example, in the future. Finally, as aspirations were only available at one time point, causal inferences are difficult to defend. Aspirations at 7 are by no means the strongest factor associated with behavioural or emotional difficulties at this age. This Research Note showed aspirations play a minor role, but it remains to be seen how they may contribute to later attainments and difficulties as the cohort grows older. Despite these caveats, this investigation showed that middle childhood is a more fruitful source of evidence on cognition about the future than has been reflected in research to date.

\section{Acknowledgements}

This research was supported by the UK Economic and Social Research Council (Grant ES/J001414/1). Millennium Cohort Study data were supplied by the ESRC Data Archive. We thank Emily Midouhas for her helpful comments. 


\section{References}

Atance, C. M., \& Melzoff, A. N. (2005). My future self: Young children's ability to anticipate and explain future states. Cognitive Development, 20, 341-361. http://dx.doi.org/10.1016/j.cogdev.2005.05.001

Auger, R. W., Blackhurst, A. E., \& Herting, W. K. (2005). The development of elementary-aged children's career aspirations and expectations. Professional School Counseling, 8, 322-329.

Bandura, A. (1995). Self-efficacy in changing societies. New York: Cambridge University Press. http://dx.doi.org/10.1017/СВ09780511527692

Bandura, A. (1997). Self-efficacy: The exercise of control. New York: Freeman.

Boxer, P., Goldstein, S. E., Delorenzo, T., Savoy, S., \& Mercado, I. (2011). Educational aspiration-expectation discrepancies: Relation to socioeconomic and academic risk-related factors. Journal of Adolescence, 34, 609-617. http://dx.doi.org/10.1016/j.adolescence.2010.10.002

Bradley, R. H., \& Corwyn, R. F. (2002). Socioeconomic status and child development. Annual Review of Psychology, 53, 377-399. http://dx.doi.org/10.1146/annurev.psych.53.100901.135233

Collins, L. M., Schafer, J. L. \& Kam, C. M. (2001). A comparison of inclusive and restrictive strategies in modern missing-data procedures. Psychological Methods, 6, 330-351. http://dx.doi.org/10.1037/1082-989X.6.4.330

Croll, P. (2008). Occupational choice, socio-economic status and educational attainment: A study of the occupational choices and destinations of young people in the British Household Panel Survey. Research Papers in Education, 23, 243-268. http://dx.doi.org/10.1080/02671520701755424

Croll, P., Attwood, G., \& Fuller, C. (2010). Children's lives, children's futures. London: Continuum.

Eccles, J. S., Adler, T. F., Futterman, R., Coff, S. B., Kaczala, C. M., Meece, J. L. \& Midgley, C. (1983). Expectancies, values and academic behaviors. In J. T. Spence (Ed.), Achievement and academic motivation (pp. 75-146). San Francisco, CA: Freeman.

Flouri, E., Moulton, V., \& Panourgia, C. (2012). Coding the aspirations of children at age 7 in the Millennium Cohort Study. MCS data note. London: Centre for Longitudinal Studies.

Flouri, E., \& Panourgia, C. (2012). Do primary school children's career aspirations matter? The relationship between family poverty, career aspirations, and emotional and behavioural problems. CLS Working Paper 2012(5). London: Centre for Longitudinal Studies.

Goodman, R. (1997). The Strengths and Difficulties Questionnaire: A research note. Journal of Child Psychology and Psychiatry, 38, 581-586. http://dx.doi.org/10.1111/j.1469-7610.1997.tb01545.x

Gottfredson, L. S. (1981). Circumspection and compromise: A developmental theory of occupational aspirations. Journal of Counseling Psychology Monographs, 28, 545-579. http://dx.doi.org/10.1037/0022-0167.28.6.545

Graham, J. W., Olchowski, A. E., \& Gilreath, T. D. (2007). How many imputations are really needed? Some practical clarifications of multiple imputation theory. Prevention Science, 8, 206-213. http://dx.doi.org/10.1007/s11121-007-0070-9

Gutman, L. M., Schoon, I., \& Sabates, R. (2012). Uncertain aspirations for continuing in education: Antecedents and associated outcomes. Developmental Psychology, 48, 1707-1718. http://dx.doi.org/10.1037/a0026547

Gutman, L. M., \& Schoon, I. (2012). Correlates and consequences of uncertainty in career aspirations: Gender differences among adolescents in England. Journal of Vocational Behavior, 80, 608-618. http://dx.doi.org/10.1016/j.jvb.2012.02.002

Helwig, A. A. (2001). A test of Gottfredson's theory using a ten-year longitudinal study. Journal of Career Development, 28, 77-95. http://dx.doi.org/10.1023/A:1012578625948

Kessler, R. C., Barker, P. R., Colpe, L. J., Epstein, J. F.,Gfroerer, J. C., Hiripi, E., Howes, M. J, Normand, S-L. T., Manderscheid, R. W., Walters, E. E., \& Zaslavsky, A. M. (2003). Screening for serious mental illness in the general population. Archives of General Psychiatry, 60, 184-189. http://dx.doi.org/10.1001/archpsyc.60.2.184

Little, R. J. A., \& Rubin, D. B. (2002). Statistical analysis with missing data (2nd ed.). New York: Wiley. http://dx.doi.org/10.1002/9781119013563

Malmberg, L. E. (2002). Adolescents' biased means and future expectations. In J. Trempała \& L. E. Malmberg (Eds.). Adolescents' future-orientation: Theory and research (Vol. 691). Frankfurt am Main: Peter Lang.

Malmberg, L. E., \& Flouri, E. (2011). The comparison and interdependence of maternal and paternal influences on young children's behavior and resilience. Journal of Clinical Child \& Adolescent Psychology, 40, 434-444. http://dx.doi.org/10.1080/15374416.2011.563469

Mau, W. C., \& Bikos, L. H. (2000). Educational and vocational aspirations of minority and female students: A longitudinal study. Journal of Counseling and Development, 78, 186-194. http://dx.doi.org/10.1002/i.1556-6676.2000.tb02577.x

Moulton, V., Flouri, E., Joshi, H., \& Sullivan, A. (Forthcoming). The role of aspirations in young children's emotional and behavioural problems. British Educational Research Journal 
Nurmi, J. E. (1991). How do adolescents see their future? A review of the development of future orientation and planning. Developmental Review, 11, 1-59. http://dx.doi.org/10.1016/0273-2297(91)90002-6

Nurmi, J. E. (2004). Socialization and self-development: Channeling, selection, adjustment, and reflection. In R. Lerner and L. Steinberg (Eds.). Handbook of adolescent psychology (2nd ed., pp. 85-124). Hoboken, NJ: Wiley.

Nurmi, J. E., \& Pulliainen, H. (1991). The changing parent-child relationship, self-esteem, and intelligence as determinants of orientation to the future during early adolescence. Journal of Adolescence, 14, 3551. http://dx.doi.org/10.1016/0140-1971(91)90044-R

Nurmi, J. E., \& Salmela-Aro, K. (2002). Goal construction, reconstruction and depressive symptoms in a lifespan context: The transition from school to work. Journal of Personality, 70, 385-420. http://dx.doi.org/10.1111/1467-6494.05009

Nuttin, J. R., \& Lens, W. (1985). Future time perspective and motivation: Theory and research method. Leuven University Press \& Erlbaum.

Plewis, I. (2007). The Millennium Cohort Study: Technical report on sampling (4th ed.). London: Centre for Longitudinal Studies.

Rotter, J. B. (1966). Generalized expectancies for internal versus external control of reinforcement. Psychological Monographs, 80, 1-28. http://dx.doi.org/10.1037/h0092976

Schoon, I., Martin, P., \& Ross, A. (2007). Career transitions in times of social change: His and her story. Journal of Vocational Behavior, 70, 78-96. http://dx.doi.org/10.1016/j.jvb.2006.04.009

Seginer, R. (2009). Future orientation: Developmental and ecological perspectives. New YorkSpringer. http://dx.doi.org/10.1007/b106810

Shanahan, L., Copeland, W., Costello, E. J., \& Angold, A. (2008). Specificity of putative psychosocial risk factors for psychiatric disorders in children and adolescents. Journal of Child Psychology and Psychiatry, 49, 34-42. http://dx.doi.org/10.1111/j.1469-7610.2007.01822.x

Wyman, P. A., Cowen, E. L., Work, W. C., \& Kerley, J. H. (1993). The role of children's future expectations in self-system functioning and adjustment to life stress: A prospective study of urban at-risk children. Development and Psychopathology, 5, 649-661. http://dx.doi.org/10.1017/S0954579400006210 